\title{
Research into the problem of classifying mythological stories according to character-based and oppositional principles
}

\author{
Olga Belugina - Svetlana Starodubets - Olga Golovacheva - Svetlana \\ Kurkina
}

DOI: 10.18355/XL.2018.11.01.26

\begin{abstract}
The relevance of this research is based on the necessity to reconstruct the ancient Slavic culture, which is impossible without taking into consideration local traditions, including those associated with the existence of non-fairy tale prose in some Slavic regions. Mythological stories of the Russian-Belorussian represent linguistic and cultural phenomenon characterized by the presence of maximally bright national and cultural features of archaic character preserved in the conditions of historical and modern intercultural interaction. The leading method of studying the mentioned problem is the method of systematization based on techniques of searching and collecting information (field research interviews, survey, and questionnaire survey). The purpose of this study is to determine the distinguishing features of classifying field research materials (in particular, mythonyms) according to character-based and oppositional principles. The folklore material (mythological stories) collected in Russian-Belorussian borderland was systematized according to both standard character-based principle and oppositional principle. This approach contributes to reconstructing the more integrated system of Slavs' representations of the world (moral beliefs, representations of space, time, and other concepts). The study proved the efficiency of the suggested classification of mythological stories for both scientific generalizations and areal research of mythonyms.
\end{abstract}

Key words: Russian-Belorussian borderland, mythonyms (characters of mythological prose), non-fairy tale prose, bylichka, byvalshchina, opposition

\section{Introduction}

A folklore study is impossible without making research on a mythological component of oral folk art objects. Accordingly, works characterized by orientation at veracity deserve special attention. In the first place, these works include associated with human mythological consciousness stories about supernatural phenomena and oral folk narratives about fantastic events, qualified as memorates and fabulates. In Russian Folklore Studies, such narratives are attributed to the genre of bylichka (superstitious memorate) or mythological story and byvalshchina (superstitious fabulate). The main function of such prosaic narratives is to inform the listener, to share every day, cosmogonic or religious information; therefore, this genre unlike, for instance, literary fairy tales is not perceived as artistic one. These are stories about people's encounters with creatures of the otherworld (mermaid, domovoy [house spirit], devil, leshy [woodland spirit], vodyanoy [water spirit], corpse, etc.), and with alive real people having superhuman abilities and/or able to establish contacts with demonic forces (healers, sorcerers, witches).

From the mid-twentieth century, folklorists around the world have faced a problem of systematizing works of small non-fairy tale prose to develop classification which could be used internationally. One can regard the indexes including a group of mythological prose (memorates and fabulates) by R. Christiansen, R. Sinninghe, L. Simonsuuri as major achievements in this field. In their classification, these scholars use thematic (character-based) principle as the basic one: which is why, they divide their work into the following sections: stories about demons, sorcerers, ghosts,

XLinguae, Volume 11 Issue 1, January 2018, ISSN 1337-8384, eISSN 2453-711X 
the deceased, witches, and so on. Nevertheless, the problem of developing more extensive classification, founded not only on character-based principle is still relevant in Folklore Studies.

Accordingly, the goal of this work is to classify modern mythological narrative (memorates and fabulates) recorded in Russian-Belorussian borderland according to oppositional and character-based principle.

The area of Russian-Belorussian borderland described in this study is characterized by peculiar ethnic features and unique traditional and material culture. South-western districts of Bryansk region (Russia), as well as eastern districts of Gomel region bordering them, are the part of Polesie. Polesie is traditionally understood as a historical and ethnographic region, which includes separate geographical areas (Belorussian, Ukrainian, Lublinskoye (Poland) and Bryansk-Zhizdrinskoe Polesie). The districts under study (Novozybkovsky, Klimovsky, Gordeevsky, Krasnogorsky, and Zlynkovsky in Russia and Vetkovsky, Dobrushsky in Belarus are located on the left bank of the Dnieper river, constituting the part of so-called Eastern (or Left-bank) Polesie. The latter also includes the Chernigov-Sumy area of Ukrainian Polesie and Gomel region of Belorussian Polesie. This region "despite global industrialization still in many respects preserves archaic characteristics of spiritual and material Slavic culture" (Belugina, 2016: 6). As N.I. Tolstoy wrote, "Some areas, despite everything, preserved their olden time features vivid insufficient completeness and variety. Polesie is one of such areas. However, even Polesie, after the catastrophe in Chernobyl, turned into a broken vessel with a gaping hole in the area of the lower Pripyat" (Tolstoy, 1995: 20). However, despite technical progress and complex environmental situation, which caused the outflow of the local population from the areas mentioned in work, narrator's belief in described events is still a constructive element of mythological stories in Bryansk-Gomel borderland. For instance, in almost every locality of the region, we documented memorates about znakhars and znakharkas [male and female healers] ; moreover, informants claimed that they approached folk healers (sheptunias, i.e., female witch doctors) for help in breaking the spell [evil eye, hex] and in solving health and family problems.

It should be noted that memorates [bylichkas] are one-episode situation-related stories, whereas fabulates [byvalshchinas] are characterized by more detailed narrative, which usually includes a sequence of different episodes associated with this or that other-worldly creature. It is not necessary to mention the names of characters, exact place and time of action in byvalshchinas; these stories are more detailed, contain more fantastic elements. Also, byvalshchinas are no longer peculiar "witness testimony"; they work as stories, which do not perform practical (informational) function, but rather aesthetic (entertaining) one.

Moreover, some researchers working on stories about the supernatural such as E.V. Pomerantseva (1968: 287) and V.P. Zinoviev (1987: 382) assert that in bylichkas [memorates] aesthetic function comes to the fore, suppressing informational function, because trust in such stories is being lost due to industrialization of society, urbanization, development of science and education.

In scientific and social terms, the importance of bylichkas and byvalshchinas is quite high, because they reflect national worldview, attitude to such concepts as time (past / future), faith, life/death, reality/unreality, as well as vision of one's place in the world, connection with family and kin.

The following features are traditionally considered to be the main attributes of mythological narrative (memorates and fabulates):

- the stories bearing a resemblance to witness testimony;

- the narrator either acts as the protagonist herself/himself, or describes the story that happened to acquaintances; when this occurs, the narrator often refers to some authoritative source of information (that is, retelling is carried out according to the stories told by one's father, mother, brother, older friend, neighbor, etc.); 
- solitary room or space familiar to narrator acts as a place of action;

- as a rule, time of action is the evening or night; the informant strives to indicate the date of the event as accurately as possible;

- an encounter with a demonic character is of markedly sudden character;

- description of feelings - fear, panic, stupor- is always present: mythological stories necessarily communicate emotional distress experienced by a person due to encounter with the supernatural (regardless of whether it is the first person narrative or retold).

Modern stories about abominable snowman, UFO, and the like certainly resonate with traditional narratives about people's encounters with evil spirits. Being one of the most ancient folklore genres, mythological prose still attracts the interest of collectors and researchers of oral tradition, as it serves as a unique source of information on the conceptual framework of the Slavic worldview.

Thus, the existence of such narratives in everyday life of the population of RussianBelorussian borderland can be regarded as a confirmation of preservation of the Eastern Slavs' archaic beliefs and pagan concepts. S.N. Starodubets (2013) wrote, "Aspects of research into general and particular patterns of ethnocultural, confessional, linguocultural ... phenomena enabling to describe Russian-BelorussianUkrainian borderland as a unique region ... are comprehensive and remain relevant. First of all, it is mixing of cultures, languages, religious beliefs, representations and rituals that have been taking place for centuries" (Starodubets, 2013: 3).

\section{Literature Review}

\section{Analysis of Russian scholarship on the topic}

Russian Folklore Studies borrowed the term bylichka from the vocabulary of peasants living in Belozersky district of Novgorod province. Brothers B.M. Sokolov and Yu.M. Sokolov introduced it in Folklore Studies: they understood bylichkas as short stories about "leshy, domovoy, cohort and chertovka [male and female demons], poluveritsa [small woodland spirit], sorcerers - In sum, about representatives of dark, evil forces" (Fairy Tales and Songs of Belozersky district, 1915: 58). Later E.V. Pomerantseva (1985) divided mythological stories into two groups: bylichkas and byvalshchinas.

Bylichka and byvalshchina, the most ancient genres of small prose in the folklore of any people, were extensively studied by folklorists, literary scholars, linguists, and ethnographers. Thus, a detailed description of Russian folklore mythological characters is given in well-known works by E.V. Pomerantseva who used the classification by S.A. Aivazyan (Pomerantseva, 1975). V.P. Zinoviev (1987) analyzed the special nature of bylichka genre in its historical and modern condition, as well as developed the detailed plot index of Siberian bylichkas and byvalshchinas. N.K. Kozlova (2000) described the Eastern Slavs' bylichkas (about the serpent and snakes); she also compiled the index of plots and texts. L.N. Vinogradova (2001), as a representative of the ethnolinguistic perspective, who described character composition, nevertheless points out that the problem of classifying characters of folk demonology is one of the least efficiently analyzed ones in modern Linguofolkloristics studying lower mythology.

Also, E.E. Levkievskaya (2007) suggested a comprehensive methodological approach to analyzing the Slavic mythological system, in which research into texts was conducted simultaneously at ethnolinguistic, dialectal and pragmatic levels. E.S. Efimova (1992) identified and analyzed main motives of mythological stories.

The following modern seminal works certainly constitute the theoretical and methodological framework of the research into non-fairy tale prose of Bryansk-Gomel borderland: ethnolinguistic dictionary edited by N.I. Tolstoy Slavic Antiquities (Slavic Antiquities: Ethnolinguistic dictionary in 5 volumes, 1995-2012), Slavic Mythology 
edited by S.M. Tolstaya (Slavic mythology. Encyclopedic dictionary, 2002), research papers by L.N. Vinogradova (2000), including Folk Demonology and Mythic-Ritual Tradition of the Slavs.

\section{Analysis of foreign scholarship on the topic}

The terms memorate and fabulate introduced by the scholar Carl Wilhelm von Sydow (1977) into Literary Studies in 1934, are used in western folklore tradition for a description of mythological stories. The Scandinavian folklorist described these terms, clarifying their differences from the narrator's perspective with respect to the narrative (that is, narrator's own or other person's experience is communicated), at the same time, he emphasized the lack of poetic design in these narratives, unlike in case of legends (impersonal stories) (Sydow, 1977). Other scholars - L. Degh \& A. Vázsonyi (1974: 239) - emphasized that the boundaries between these types of narrative stories (memorates, fabulates, and legends) are quite blurred, so they saw no point in distinguishing between them.

It should be noted that most scientists, both in Russian and foreign folklore tradition, categorize bylichkas and byvalshchinas according to only character-based principle also taking into consideration plots and motives of folklore works. We believe that this classification principle is a traditional one; it is necessary to extend it through local versions of the modern mythological narrative.

We suppose that the most relevant problem is developing an oppositional principle for classification of mythological narrative, which registers, on the one hand, cognitive foundations of the Eastern Slavs' modern worldview which preserved archaic characteristics, and, on the other hand, the deep conceptual parameters of the systemstructural organization of folklore texts.

\section{Methods and Materials}

The method of systematization of mythological stories has become the leading one in this research. In addition, in the course of studies into small mythological prose of Russian-Belorussian borderland, systematization of folk mythological characters and folk representations of residents associated with them, the following basic methods of field research from Folklore Studies were employed: longitudinal study, methods of ethnolinguistic analysis of linguistic material, descriptive method, and lexicographic definition method.

The method of systematization meant categorization of mythological stories based on oppositional and character-based principles into separate groups, characterized by certain common and distinguishing features. The method of classification of information collected in the course of field trips was used as the main way of systematization.

Methods of field research were used directly for collecting folklore material during folklore and ethnographic expeditions aimed at preserving folk cultural heritage. To accomplish the purpose of this study, we used the method of specialized expedition oriented at investigating certain phenomena or genres of folklore on the particular topic; at supplementing and extending available data; search for certain rarities, masters, etc. In particular, we undertook an expedition to the areas in which respondents lived to whom certain superpower was attributed. Surveys and interviews were of narrowly specialized nature and concerned directly small forms of non-fairy tale prose. The research target group included residents of borderland towns, villages and hamlets of Russia and Belarus. The research covered respondents between 40 and 80 years old.

The method of longitudinal study is associated with multiple research into the same folklore objects over long periods of time and involves conducting repeated surveys in the same localities to document changes like certain mythological stories in given settlements. 
Methods of ethnolinguistic analysis of linguistic material are aimed at studying the interplay between the language and the culture, the interaction of linguistic and ethnocultural factors in functioning and evolution of the language. This research was conducted with direct use of the ethnolinguistic method of integrated contrastive analysis, aimed at search for ethnographic, folklore and linguistic similarities and differences in bylichkas and byvalshchinas collected in different areas of the RussianBelorussian borderland.

The descriptive method was employed for both initial processing and in-depth analysis of the data. We carried out categorization of mythological stories into groups using this method, which enabled us to study the peculiar nature of bylichkas and byvalshchinas both from the perspective of defined qualities (types of characters) and from their opposition-related characteristics.

The method of the lexicographic definition was applied to define the meaning of lexical units, denoting names of mythological characters. The descriptions were composed based on the data from various dictionaries to obtain the fullest possible reproduction of semantics of the linguistic units under study.

\section{Research Findings}

In the course of studying folklore mythological stories collected on the territory of Russian-Belorussian borderland, we found out their following peculiar features:

- Mythological prose of the mentioned region is endowed with characters, the composition of which in many respects coincides with Russian (and Belorussian) categorization of lower mythology characters, but there are also unique local features peculiar to borderland inhabitants' representations of these characters;

- one can distinguish between the following main thematic groups of characters close to the concept of human being in non-fairy tale prose of Bryansk-Gomel borderland: mythological images of people having certain superhuman abilities; people subjugated by evil spirits, abducted by them; people who acquired demonic abilities intentionally coming into contact with evil spirits;

- The research revealed some oppositions associated with a group of characters purposefully asking creatures of the otherworld for help. These creatures include vedmy/vedmaki [female/male witches], koldunias (koldovkas)/kolduns [female/male sorcerers]; znahars/znaharkas (sheptuns/sheptalkas) [male and female witch healers], vorozheyas/vorozhkas [fortune-tellers]. The main oppositions harm-good, diseasehealth, death-life, anguish-happiness were determined due to, first of all, purposeful use of superhuman abilities;

- Opposition-related characterization of such mythological characters as dobrohozhy [invisible, white people [or veduns [enchanters] includes such oppositions as within the borders-beyond the borders, the familiar - the alien, this world - the otherworld;

- Use of oppositional principle for describing mythological narrative allows us to register deep textual characteristics determining its cognitive features, namely, irrationality, dialogism, the dualism of described action represented in reality, but referring respondent to the focus of the unreal.

\section{Discussion}

As we noted above, structural-thematic (character-based) principle of classification is the most common and mainstream one. According to this principle, thematic groups of memorates directly related to particular characters (nature spirits, devil, serpent, sorcerers, vampires, UFOs) are distinguished. The classification of character composition of folk demonology developed by L.N. Vinogradova (2001) is fairly detailed. In the process of systematization, the scholar starts from the opposition 
person-inhuman being/demon. In our work, the first part of this opposition, i.e., mythological characters related to the concept of person was subjected to the analysis. L.N. Vinogradova (2001) divides them into the following groups: 1) mythological images of people (temporarily or permanently) having some superhuman abilities (for example, people who have malevolent glare, who can read fortune, practice sorcery, heal, break hex; people who know the secrets of mastership -the so-called knowledgeable (shepherds, carpenters, potters, blacksmiths, millers, horse-leeches, musicians, etc.) 2) <..> images of people who became evil spirits' victims (demoniacs, the possessed, those obsessed by demons, klikushi [possessed women], holy fools). <...> 3) people at some point abducted by evil spirits, subjugated by them, or turned into animals (podmenyshi [changelings], cursed children, the invisible, oborotni [were-animals], vovkulaki [werewolves], etc.), <... 4) the images of dvoedushniki [double-souled people] who, according to popular beliefs, have a second "demonic" soul (for example, such characters of Carpathian mythology as zmara [ghost], bosorkanya [witch], planetnik [astrologist], chernoknozhnik [black magician], as well as those who 5) intentionally came into contact with evil spirits and due to it acquired evident demonic properties (witches, sorcerers, witch doctors, wizards, enchanters, etc.), $<\ldots>6$ ) the souls of deceased relatives (still remembered using their names) or righteous parents-ancestors, who visit their houses on earth on particular commemoration days. <... 7) evil "zalozhnye pokoiniki" - the dead (suiciders, dead sorcerers, and witches, the walking dead, various kinds of spirits and ghosts). 8) The next group consists of characters (possessing certain demonological features), whose background, according to folk beliefs, is associated with the category of deceased people's souls (vampire, domovoy [house spirit], mermaid, children who died unbaptized, etc.) (Vinogradova, 2001).

The fifth group of the ones mentioned above is most widely represented on the territory covered by the survey; within it the functional opposition harm/disease/death/anguish - good/health/life/happiness is discerned. The first part of the opposition is associated with such mythological characters as vedmas/vedmaks [female/male witches], koldunias (koldovkas)/kolduns [female/male sorcerers], etc. Representatives of this array possess superhuman abilities through which they deliberately inflict damage on others; they can also communicate directly with certain mythological characters of the group of "non-human beings," i.e., chorts [demons], the devil, Satan. Accordingly, basic plots of bylichkas and byvalshchinas reflect the following motives:

- Oborotnichestvo [shapeshifting] (transformation either into an animal (a cat, a pig, a horse, a dog, a toad) or into an object (a wheel, a ball, a haycock, a hoop));

- Planting of cursed objects (food, needles, pins, graveyard dirt);

- Placing curse/evil eye on people and domestic animals (child's fear, stealing milk from cows).

The presence of similar motives determines the plots on the following topics documented in Bryansk-Gomel borderland:

- Identification of witches (all over the region under study memorates and fabulates are documented, which describe doing an injury to a witch who shapeshifted into an animal or an object and her next day identification by her bandaged (cut off) hand or her poked out eye, etc.);

- protection from witches/punishment of a witch;

- the penalty of witches (the motive of difficult death).

For instance, "Witches are those who sold their souls not to God, but rather to Satan; and they serve him. Witches have a special law called "Black Magic," according to which they live; they read it and shapeshift. Once, there was a story: my grandmother's kuma [godmother of my granmother's child] came to work and often slept at work -sometimes she fell asleep just for one minute. My grandmother said to her, "I know that you practice magic (practice witchcraft)." Moreover, the kuma 
replies, "Don't speak of it so loudly." Then my grandmother asked, "They say that a witch's soul can pass to a cat, a pig, or a horse. Tell me, what animal is more difficult to pass to?" She said, "To a cat." That is, when this occurs, the human body lies like a corpse, while the soul enters any animal - end of the story; from now on she [witch] controls this animal, she can bite herself. [Why does she do it?] She needs to do people harm in some way; she said that only twice a year she could do something good if somebody asks her for it. She could not do other than does, as she sold her soul to Satan. They do not benefit from the harm they do; they cannot help doing people harm as Satan controls them. $<\ldots>$

This gift is not inherited. There was also a story, I, myself, heard straight from the horse's mouth. There was a family, who lived on the village outskirts, in a house closest to the fields. Children grew up and left, a grandfather died, only a grandmother stayed in the house, and she fell very ill. Her son came. He did not find her in the house, so went to the barn and called his mother. She responded to his call and began to call, to ask him to enter the barn. He just crossed the doorstep and immediately fell to the ground, got speechless and turned grey out of fear. Moreover, the mother pulls her hands to him and says, "Come, come here, son." He managed to run out of the barn; he spent the night in our house. We do not know what happened to her later. I do not know how she could die.

They say, when a witch dies, they break a hole in the house roof because her soul rushes and cannot leave the body. If you enter her house at this moment, she will ask you to bring her some water to drink. As soon as he takes this glass from you, her evil gift will be transmitted to you; then she will die.

After the death of that witch [* the one who died in the barn], her house was burnt. They found a book "Black magic" on the stove. They say that witch milked cows at night. My grandmother once went into the barn and saw her cow already milked and ill. Grandmother went to the witch and threatened to cut off her head. The witch sent her home, and in three days, the cow recovered.

Moreover, my father also told me a story. He was going home from his fiancée when suddenly a cat jumped under his feet. He began to defend himself against it and fell into a deep hole, from which he could not get out. Getting exhausted, he fell and closed his eyes. When he opened them again, there was neither cat nor hole absolutely nothing. He was just lying on the grass". (Recorded according to information provided by N.A. Lopukhova (1967), Novozybkov, Bryansk region, Russia).

Also, stories are documented in which male and female possessors of negative supernatural gifts can cause others harm unwillingly. In the region under study, such people are also referred to as either witch or "kind people who have an evil eye by nature." In this case, according to the classification by L.N. Vinogradova (2001), the fifth group (i.e., those who intentionally came into contact with evil spirits) is connected with the first group (mythological images of people having some superhuman abilities).

The second part of the opposition we describe (good/health/life/happiness) includes such mythological characters as znahars/znaharkas (sheptuns/sheptalkas) [male and female witch healers], vorozheyas/vorozhkas [fortune-tellers]. These representatives of people's world (both men and women) can communicate with creatures of the otherworld, using these contacts for people's well-being. First of all, they can neutralize the damage caused by representatives of the other part of the opposition (evil eye, curse); meanwhile, no direct contacts between them and demonic characters (chort, the devil) are traced. As we noted above, recourse to znakhars [healers] in Russian-Belorussian borderland is quite widespread. Accordingly, we documented quite a large number of stories about miraculous recoveries contrary to doctors' diagnoses. Polessian healers sometimes fulfill the functions of psychotherapists for

XLinguae, Volume 11 Issue 1, January 2018, ISSN 1337-8384, eISSN 2453-711X 
the local population, helping people to solve personal problems, for example, dealing with adultery, the death of the loved ones, etc.

Also, in many mythological stories, healers had psychic abilities (they can see the future, find lost items and missing people). Virtually any resident of the studied region can become a client of traditional healers, regardless of education (secondary or higher), social status (peasant, worker or member of the intelligentsia), place of residence (hamlet, village, city). Stories are documented about recourse to healers even by people with medical education. "There was an old lady, called Nastya. What a pity she is dead now. She helped people with her prayers, predicted the future using divination cards. She was addressed if a person went missing or documents, for example, were lost. She defined where the things were. She said, "Look, they are in another place." Once, in our village a person went missing; his mother came to Nastya, she laid out divination cards and said, "You will find him soon. Everything will be fine. He will turn up, you will hear from him." Moreover, it happened this way. She was a good woman; she used to heal: she said a prayer and then rolled a piece of the soft part of the bread. She rolled a piece of the soft part of bread into a ball and said something; I do not know what. Afterwards, this bread ball had to be given to dogs on the way home. Moreover, it helped - disease was cured, and evil eye was broken. 〈...>. She did not set a price for treatment for anyone. People gave her whatever they wanted - the money, the food. She, herself, said nothing about the price; but she received everybody, helped even the unbaptized. She was a nice woman; once, even a doctor took his children to her place - our pediatrician." (Recorded according to the information provided by Lidia Leonidovna Smetanko, born in1952, village of Tvorishino, Gordeevsky district, Bryansk region, Russia).

It should be noted, that the opposition described above does not work all over the territory of Bryansk-Gomel borderland. Although in most cases informants defend their claim that znaharkas [female witch healers], unlike witches, do only good to people, acting exclusively in people's interests and do not do harm at all, but there are documented narratives in which healers emerge as changed people - kolduns [male sorcerers [, who embarked upon the right path.

Other mythological characters among original representatives of the folk demonological prose of Bryansk-Gomel borderland are dobrohozhie [the invisible, white people or veduns (enchanters)]. According to Belorussian scholar G.I. Lopatin, these demonic creatures combine features peculiar to "domovoy [house spirit], polevoy [spirit of the field], lesovoy [woodland spirit], and sometimes even mermaids" (Lopatin, 2012). From the perspective of character-based classification by L.N. Vinogradova (2001), they correlate above all with the third group, i.e., with people at some point abducted by evil spirits, subjugated by them. In the plots of bylichkas and byvalshchinas describing encounters with these characters, there is a common motive of "place/border/passage" - a peculiar "portal" through which they penetrate into the world of real people. It can be a border in the kitchen garden, a place in the garden (usually under apple trees), a path in the field, some part of the road, etc. Many narratives on dobrohozhie accentuate the need for taking care of these places (not to litter, not to defecate, not to damage or leave anything, it is better not to walk there at all): "In old times, a large willow grew near the road. Under it, every night a young couple in white [dobrohozhie] was seen. Our chairman asked to cut this willow. Moreover, they cut. Subsequently, on this road, five people died in road accidents" (Recorded according to information provided by Nina Pavlovna Gritsian, born in 1953, Larnevsk village, Krasnogorsk district, Bryansk Region, Russia).

Therefore, from the perspective of the oppositional characteristics, one can see the presence in this cycle of memorates and fabulates of the opposition within the borders (that is, "our own/our/this world") and of the opposition beyond the borders (that is, "unfamiliar/the otherworld"). The first part of the opposition is represented in oral stories describing encounters/acts of communication between people and dobrohozhie 
in real everyday life, in familiar situations (in the field, in the garden, in the kitchen garden, on the road, in the house, in the banya, etc.); the narratives also described the consequences (strong fear, illness) caused by this encounter. For instance: "My brother was walking to Morozovka [* a village in Krasnogorsky district of Bryansk region]. He walked alone; there was nobody around. Suddenly he noticed a man walking next to him. The man asked my brother for a cigarette. The brother effed and blinded him. Suddenly the brother went down like a tree; he could not feel his legs and could not walk. Behind him, Belorussian builders were walking. They helped him to stand up. They brought him to our house. Moreover, my mother began to the charm. He felt his legs again and stood up." (Recorded according to information provided by Nina Pavlovna Gritsian, born in 1953, Larnevsk village, Krasnogorsk district, Bryansk Region, Russia).

Also, there are documented narratives, which describe the cases of mythological creatures' return from their world to the real one, which usually becomes possible due to the assistance of the clergy: "A guy (an invisible one) fell for a maid. He began to go to her place and to take her to banya [bathhouse]. In the banya, they lived, and the girl became pregnant. Parents followed her and found out where she went. After she entered the banya, they locked her in it and ran for the priest. They came with the priest, drew a cross on the door, and blessed the door with the sign of the cross. Moreover, they went out: he [*an invisible], and that girl, and their child. They left the banya and never lived there anymore. [Why did they come out?] They were blessed with the sign of the cross; the priest blessed them all: both the child and him. Moreover, he became visible. (Recorded according to information provided by Efrosinya Ivanovna Demchikhina, born in 1935, Neglyubka village, Vetkovsky district, Gomel Region, Belarus)

The second part of the opposition (beyond the borders meaning "unfamiliar/the otherworld") is reflected in narratives, which describe, as a rule, person's visual impressions (most common of them are the stories about seeing a house or a family of dobrohozhie); these narratives describe crossing the symbolic border between the real world and the otherworld implemented due to help of mythological character:

"When I was a kid, there were dobrohozhie. They were invisible people. There was a man in our village, who told that he did not believe in them. When his neighbor told him about an encounter with dobrohozhy, he did not believe it. The uncle went to the banya in the afternoon, during the most extreme heat. He washed and was about to leave when suddenly a man appeared and grabbed him by the arm. The stranger asked, "Do you believe?" The man said, "I believe." The stranger turned around and walked. The man stood up and followed him in silence. He jumped over the fence and saw a house; in the house, there were three rooms (he did not sleep, but everything was like in a dream). In the house a woman was sitting - she was handsome, slim, with black hair, elegant, dressed in embroidered blouse and Sarafan. The stranger [* dobrohozhy] silently greeted her, without saying "hello." Moreover, the man kept copying everything the stranger did: he also silently greeted her. The stranger passed through three rooms and went out. The man followed him. Suddenly the stranger slammed the door. Uncle woke up and saw that he was standing on the meadow next to three dug over garden beds. Then he went back home". (Recorded according to information provided by Anna Prokofyevna Borovik, born in 1935, village of Perelazy, Krasnogorsk district, Bryansk Region, Russia).

Thus, the analysis of the most remarkable characters of bylichkas and byvalshchinas represented on the territory of Russian-Belorussian borderland demonstrated that the study of small mythological regional prose applying character-based, structuralthematic and oppositional classification principles allows not only to systematize mythological characters but also to identify folk representations associated with them,

XLinguae, Volume 11 Issue 1, January 2018, ISSN 1337-8384, eISSN 2453-711X 
which are sources of ethnolinguistic information.

\section{Conclusion}

In the course of the research, the authors tried to develop modern criteria for the systematization of field research material and scientific generalizations, which included classification of mythological stories and mythological characters of Bryansk-Gomel borderland using character-based and oppositional principles. Since modern Folklore Studies pay considerable attention to problems of reconstructing the Slavic intellectual culture, such description can contribute to research into the spiritual culture of the Slavs and serve as one of the sources for reconstructing its most ancient form. Mythological stories recorded in the territory of the Russian-Belorussian borderland are the fact of folk literature based on veracity. Patterns of oppositions selected in the course of character-based classification not only provide a more detailed description of mythonyms but also reveal distinguishing features of Eastern Slavs' perception of such categories as reality and unreality, good and evil.

The prospects for further research of memorates and fabulates in Russian-Belorussian borderland are as follows:

- development of authorial criteria for a functional and gender-based description of mythonyms, represented in the context of small mythological prose works of Bryansk-Gomel borderland and respondents' consciousness;

- differentiation and systematization of linguistic means documenting the mythology of material, plant and animal universes and others, represented through the symbolic component of word's lexical meaning used in the context of non-fairy tale prose (bylichkas and byvalshchinas) of Bryansk-Gomel borderland.

The presented material can also be used in lexicographical practice for compiling dictionaries of dialect vocabulary, as well as dictionaries of folklore language and folk culture. Ethnolinguographic data can be used in teaching courses: for giving lectures and conducting seminars and practical classes in Folklore Studies, Russian Dialectology, and Ethnography. Students may employ the data while writing course works and graduate qualification theses. It is possible to use the data obtained during this research in the course of developing special courses on issues of Folklore Studies, Cultural Linguistics and Ethnolinguistics, as well as special courses related to teaching Russian to foreigners. Also, staff members of cultural and educational institutions can use the data presented in the article for the reconstruction and reproduction on a massive scale of fragments of folk culture, reflecting representations of mythological characters.

\section{Acknowledgment}

The publication was prepared within the framework of Research Project No. 17-2401002a (m) supported by the Russian Foundation for Basic Research.

\section{Bibliographic references}

BELUGINA, O. V. 2016. Special Features of Ceremonial Vocabulary Functioning in the Folklore of Southwestern Districts of Bryansk region. Ph.D. Thesis (Philology). Bryansk. Available online: http://www.smolgu.ru/files/doc/D212_254_01/disser/Belugina.pdf [in Russian].

CHRISTIANSEN, R. Th. 1977. The Migratory Legends. List of Types with a Systematic Catalogue of the Norwegian Variants (International Folklore). Ayer Co Pub. [in English]. ISBN-13: 978-0405100871, ISBN-10: 0405100876.

DÉGH, L., and VÁZSONYI, A. 1974. The Memorate and Proto-Memorate. In: Journal of American Folklore, vol. 87, n. 345, pp. 225-239. DOI: 10.2307/538735. ISSN: $15351882,00218715$.

EFIMOVA, E. S. 1992. The Main Motives of Russian Bylichkas. Model of Classification. In Prokofiev, N. I. (Ed.) Fairy tale and non-Fairy-tale Prose. Inter- 
university collection of articles (pp. 52-63). Moscow: Prometey. http://www.ruthenia.ru/folklore/efimova7.htm [in Russian].

KOZLOVA, N. K. 2000. East Slavic Bylichkas about the Serpents and snakes. In Smirnov Yu. I. (Ed.) Mythical Lover. Index of stories and texts (pp. 248-252). Omsk: Omsk State Pedagogical University Press. [in Russian] Available online: http://www.ruthenia.ru/folklore/kozlova1.htm ISBN: 9785826803844 [5826803843]

LEVKIEVSKAYA, E. E. 2007. East Slavic Mythological Text: Semantics, Dialectology, Pragmatics: Ph.D. Thesis (Philology). Moscow. [in Russian]. Available online: http://www.ruthenia.ru/folklore/levkievskaya4.htm

LOPATIN, G. I. 2012. About the Folk Demonology of Belorussian-Bryansk borderland: Dobrohozhie, the Invisible, and others. Vetka. Available online: http://vetka-museum.by/publikatsyi-supratso-nika/146-o-narodnoj-demonologii-

belorussko-bryanskogo-pogranichya-dobrokhozhie-nevidimye-i-dr.html. [in Russian]. POMERANTSEVA, E. V. 1968. Genre Features of Russian Bylichkas. History, Culture, Folklore, and Ethnography of the Slavic peoples. The VI International Congress of Slavists (pp. 274-293). Moscow. [in Russian]. Available online: http://inslav.ru/images/stories/pdf/1968_Istorija_kul\%27tura_fol\%27klor_i_etnografij a_slav\%27anskix_narodov.pdf

POMERANTSEVA, E. V. 1975. Mythological Characters in Russian Folklore. Moscow: Nauka. ISBN: 978-5-699-27982-1; ISBN: 5-91016-014-3. [In Russian].

POMERANTSEVA, E. V. 1985. Russian Oral Prose. Moscow: Prosveshchenie. ISBN: 5-265-01083-1 [in Russian].

SIMONSUURI L. 1991. Typen und Motivverzeichnis der finnischen Sagen. Translated into Russian. Petrozavodsk: Karelia. ISBN: 5-7545-0556-6.

SINNINGHE, R. W. 1943. Katalog der niederländischen Märchen, Ursprungssagen, Sagen und Legendenvarianten. In: FFC, vol. 55, no. 132. Helsinki: Suomalainen Tiedeakatemia COBISS.SI-ID 35443554.[in German].

STARODUBETS, S. N. 2013. Slavic Studies in the Border Region: BelorussianUkrainian Interaction. In Russian-Belorussian-Ukrainian Borderland: Problems of Interaction in the Context of the Common Social and Cultural Space - History and Prospects: Proceedings of International Scientific Conference (Novozybkov, Bryansk region, October 17-18, 2013) (pp.3-5). Novozybkov. [in Russian].

SYDOW, C. W. von. 1977. Selected Papers on Folklore. Ayer Co Pub. ISBN10: 0405101252 ISBN-13: 978-0405101250 [in English].

Tales and Songs of Belozersk region. 1999. Collected by B. Sokolov and U. Sokolov. Saint Petersburg: Tropa Troyanova. ISBN 5-89798-002-0, 5-89798-005-5 [in Russian].

TOLSTAYA, S. M. (Ed.). 2002. Slavic Mythology. Encyclopedic Dictionary. Moscow: Mezhdynarodnye Otnosheniya. ISBN 5-7133-1069-8 [in Russian].

TOLSTOY, N. I. (Ed.). 1995-2012. Slavic Antiquities: Ethnolinguistic Dictionary in 5 volumes. Moscow: Mezhdynarodnye Otnosheniya. ISBN: 5713307034 / 5713307042/5713309827/5713312070/9785713313128/9785713313807 [in Russian]. TOLSTOY, N.I. 1995. Language and Folk Culture. Essays on Slavic Mythology and Ethnolinguistics. Moscow: Indrik Publishing House. ISBN: 5-85759-025-6 [in Russian].

VINOGRADOVA, L. N. 1994. What do We Know about Mermaids? Living Antiquity, no. 4, pp. 28-31, ISSN 0204-3432. [in Russian].

VINOGRADOVA, L. N. 1995. Regional Features of the Polesie Beliefs about Domovoy. In Tolstoy, N.I. (Ed.) Slavic and Balkan Folklore: Ethnolinguistic Study of Polesie. (pp. 142-152). Moscow: Indrik Publishing House. ISBN: 5-85759-030-2. [in Russian].

VINOGRADOVA, L. N. 2000. Folk Demonology and Mythological-Ritual Tradition of the Slavs. Moscow: Indrik Publishing House. ISBN: 5-85759-110-4 [in Russian].

XLinguae, Volume 11 Issue 1, January 2018, ISSN 1337-8384, eISSN 2453-711X 
VINOGRADOVA, L. N. 2001. Slavic Folk Demonology: Problems of Comparative Study. Ph.D. Thesis (Philology). Moscow. Available online: http://www.ruthenia.ru/folklore/vinogradova1.htm [in Russian].

ZINOVIEV, V. P. 1987. Bylichka as a Folklore Genre and its Contemporary State. In Mythological Stories of the Russian Population of Eastern Siberia, compiled by Zinoviev, V. P. 1987. (pp. 381-400). Novosibirsk: Nauka, Siberian Department. ISBN: 978-5-458-42371-7 [In Russian].

Words: 6443

Characters: 45069 (25,04 standard pages)

Professor Svetlana Starodubets, Doctor of Sciences (Philology)

Socio-Economic and Humanities Department

Bryansk State University named after Academician I.G. Petrovsky, a branch in Novozybkov,

Sadovaya street, 23, apt 8,

Novozybkov, 243020, Bryansk Region,

Russia

sstarodubets@yandex.ru

Senior lecturer Olga Belugina, Candidate of Sciences (Philology)

Socio-Economic and Humanities Department

Bryansk State University named after Academician I.G. Petrovsky, a branch in Novozybkov,

Station Street, 44-v, apt 47,

Novozybkov, 243020,

Bryansk Region,

Russia

beluginaol@yandex.ru

Associated Professor Olga Golovacheva, Doctor of Sciences (Philology)

Department of Russian language

Bryansk State University named after Academician I.G. Petrovsky

Bezhitskaya the house 16 , case $2 \mathrm{~b}$, apt 214

Bryansk, 241036,

Russia

olhagolovacheva@yandex.ru

Laboratory assistant Svetlana Kurkina

Socio-Economic and Humanities Department

Bryansk State University named after Academician I.G. Petrovsky, a branch in Novozybkov,

Lomonosov street, 24 , apt 72,

Novozybkov, 243020,

Bryansk Region,

Russia

kurkinalana@yandex.ru 